Vol. 40: 23-29, 2012

\title{
Effect of cyanobacteria on growth and yield of boro rice under different levels of urea
}

\author{
Wahida Khatun ${ }^{1}$, Md. Mosleh Ud-Deen ${ }^{2 *}$ \& Golam Kabir ${ }^{3}$ \\ ${ }^{1}$ Department of Botany, Durgapur Degree College, Rajshahi, Bangladesh; \\ ${ }^{2}$ Department of Crop Science \& Technology, University of Rajshahi, Rajshahi 6205, Bangladesh; \\ ${ }^{3}$ Department of Botany, University of Rajshahi, Rajshahi 6205, Bangladesh. \\ *Corresponding author: uddeenm@yahoo.com
}

\begin{abstract}
A pot culture and a field experiment were conducted with cyanobacteria in presence and absence of different levels of urea to evaluate their effects on growth and yield of rice cv. BRRI Dhan 28, 29 and 36 during Boro season of 2007. The treatments were $\mathrm{T}_{1}$ (control), $\mathrm{T}_{2}$ (only cyanobacteria), $\mathrm{T}_{3}$ (recommended doses of urea - $60 \mathrm{~kg} \mathrm{~N} / \mathrm{ha}$ ), $\mathrm{T}_{4}$ (45\% recommended doses of urea + cyanobacteria), $\mathrm{T}_{5}$ (65\% recommended doses of urea + cyanobacteria) and $\mathrm{T}_{6}(85 \%$ recommended doses of urea + cyanobacteria). The maximum values for different growth, yield and yield components (plant height, number of productive tillers/hill, panicle length, number of grains/panicle, 1000-grain weight, and grain, straw and biological yield) were observed in BRRI Dhan 29 under $\mathrm{T}_{6}$ (85\% recommended doses of urea + cyanobacteria) and lowest was observed in BRRI Dhan 28 under $T_{1}$ (neither urea nor cyanobacteria). Uses of cyanobacteria increased the yield of Boro rice varieties and decreased the use of urea by $15-20 \%$.
\end{abstract}

Keywords: Cyanobacteria and urea, growth and yield, boro rice.

\section{Introduction}

Rice is the staple food for more than $60 \%$ of the worlds' population and it is being grown in this sub-continent from time immemorial. Nitrogen $(\mathrm{N})$ is an essential nutrient element for plants and is needed in large quantities for high yield of crops. Bangladesh soils are deficient in $\mathrm{N}$ and consequently the response of modern rice varieties to $\mathrm{N}$ application has always been observed remarkable (Chowdhury \& Bhuiyan, 1999). The $\mathrm{N}$ deficiency is one of the most common yield limiting factors in rice soils of Bangladesh (Mian, 1994). Application of $\mathrm{N}$ through different sources influences the activity of the microbes involved in the $\mathrm{N}$ transformation, and in turn, the availability of inorganic $\mathrm{N}$ increases in soil and yield of rice improves. Unfortunately, the $\mathrm{N}$ reserve of Bangladesh soil is very low (Islam, 1984) and supplementary use of $\mathrm{N}$ is essential for better crop production. Moreover, urea depletes the organic matter status in soils (Sattar, 1972). The high price and scanty of nitrogen fertilizer is one of the problems for rice production in rice producing countries. Biofertilizer is the cheaper source of nutrients in soil and is friendly to environment.

Cyanobacteria are a diverse group of procaryotes. In view of the global energy crisis, bio-fertilizers such as cyanobacteria and Azolla are important supplementary nitrogen sources in rice cultivation (Chowdhury \& Bhuiyan, 1999). Additionally, cyanobacteria bring about changes in chemical and electro-chemical properties of the soil. This can modify the oxidation-reduction status of the rice growing soil and the chelating capacity of the soil organic matter, which in turn may bring about changes in the availability of different micronutrients like $\mathrm{Fe}, \mathrm{Cu}$, 
$\mathrm{Zn}$ in soil. The use of cyanobacterial bio-fertilizer for rice culture has been gaining importance due to increased crisis and production cost of nitrogen fertilizer especially in developing counties like Bangladesh. The farmers of Bangladesh grow rice during Boro season with irrigation water maintaining a 3-5 cm water level for at least 30-40 days and this time should be sufficient for growing large amounts of cyanobacteria (Sattar, 1972). Moreover, the production technology of cyanobacteria is easy and it does not require an extra land. Thus, there is an ample scope of growing cyanobacteria simultaneously with Boro rice. The present experiment was conducted to finding out the effects of cyanobacteria and urea on Boro rice in earthen pots and to determining the effect of cyanobacteria on Boro rice during their growing seasons in the experimentation fields.

\section{Materials and methods}

A pot culture experiment and a field experiment were conducted at Rajshahi University from Rajshahi during Boro season of 2007. The land was medium high having sandy loam in texture under the "High Ganges River Flood Plain” (AEZ12) with $\mathrm{pH} 7.8$, organic matter $1.18 \%$, total $\mathrm{N} 0.09 \%$, available $\mathrm{P} 15 \mu \mathrm{g} / \mathrm{g}$ soil, available K 0.165 meq/100g soil, available S $20 \mu \mathrm{g} / \mathrm{g}$ soil and available Zn 1.35 $\mu \mathrm{g} / \mathrm{g}$ soil. The experiment was designed following a two factorial (variety and treatment combination) Randomized Complete Block Design (RCBD) where each treatments were replicated thries. The rice varieties were BRRI Dhan 28, 29 and 36. The treatments were $\mathrm{T}_{1}=$ control (no urea or cyanobacteria), $\mathrm{T}_{2}=$ only cyanobacteria, $\mathrm{T}_{3}=$ recommended doses of urea $(60 \mathrm{kgN} / \mathrm{ha}), \mathrm{T}_{4}=45 \%$ recommended doses of urea + cyanobacteria, $\mathrm{T}_{5}=65 \%$ recommended doses of urea + cyanobacteria and $\mathrm{T}_{6}=85 \%$ recommended doses of urea + cyanobacteria. In case of pot culture experiment, bottom sealed earthen pots having $30 \mathrm{~cm}$ height and $40 \mathrm{~cm}$ diameter were used. The pots were filled with $15 \mathrm{~kg}$ soil leaving $10 \mathrm{~cm}$ height above for holding the water. The Urea, Triple Super Phosphate (TSP) and Muriate of Potash (MP) at the rate of 180,160 and $50 \mathrm{~kg} \mathrm{ha}^{-1}$, respectively were applied in all the pots before transplantation of the rice seedlings. Cyanobacteria were applied at the rate of $0.5 \mathrm{~kg} \mathrm{~m}^{-2}$ in pots and each lot was filled with water up to $4-5 \mathrm{~cm}$. depths before inoculation (BARC, 1998). In field experiment, the unit plot size was $2.5 \mathrm{~m} \mathrm{X} 2.0 \mathrm{~m}$. Fertilizers were applied as the same rate used in pot. Total MP and TSP were applied during land preparation. Urea was applied with three equal splits at 20, 30 and 50 days after transplantation of seedlings.

The 30 days old seedlings of rice were transplanted having three seedlings per hill maintaining a spacing of $20 \mathrm{~cm}$ X $15 \mathrm{~cm}$. Cyanobacterial inocula were applied @ $0.5 \mathrm{~kg} / \mathrm{m}^{2}$ (fresh weight) in the plots and each plot was filled with water up to 4-5 $\mathrm{cm}$ depths before inoculation. Irrigation water was applied when necessary to maintain about $5 \mathrm{~cm}$ of water height on the land surface. Intercultural operations were done when it was necessary. First weeding was done after 40 days and another after 50 days of transplanting. The excess seedlings were plucked out during first weeding. The field was irrigated twice. First irrigation was done at 40 days after transplanting second irrigation was done after 50 days of transplanting. Plants were harvested after attainment of their full maturity stage. Data on growth and yield contributing characters were taken. The values for grain and straw yield were calculated at $18 \pm 2 \%$ moisture content in pot and $22 \pm 2 \%$ moisture content in field trial. The findings from the experiments were analyzed statistically using 
MSTAT - C package program. The mean values were compared by Duncun's Multiple Range Test (DMRT) along with the estimation of LSD value (Gomez \& Gomez, 1984).

\section{Results and discussion}

Plant height

Plant height of three varieties of Boro rice were found to be vary among different treatments both in pot and field trails (Table 1). In pot trail, the highest plant height was found in BRRI Dhan 29 under $\mathrm{T}_{1}$ and $\mathrm{T}_{6}$ treatments and the lowest was observed in of BRRI Dhan 28 under $\mathrm{T}_{1}$. In case of field trail, the highest plant height was also observed in treatment BRRI Dhan 29 under $\mathrm{T}_{6}$ which was significantly different from that of all other treatments whereas the lowest was found in BRRI Dhan 28 or BRRI Dhan 36 under $\mathrm{T}_{1}$ treatment. This finding agreed with the finding of Karim \& Rahaman (1992). They obtained highest plant height and panicle length due to $\mathrm{N}_{60}+$ cyanobacteria treatment. The increased in plant height of rice as influenced by cyanobacteria were also reported Kannaiyan et al. (1989).

Table 1. Effect of cyanobacteria on the growth of boro rice with different levels of urea both in pot and field trails.

\begin{tabular}{|c|c|c|c|c|c|c|c|c|c|}
\hline \multirow[t]{2}{*}{ Varieties } & \multirow{2}{*}{$\begin{array}{l}\text { Treat } \\
\text { ments }\end{array}$} & \multicolumn{2}{|c|}{$\begin{array}{l}\text { Plant height } \\
(\mathrm{cm}) \text { at maturity } \\
\text { stage }\end{array}$} & \multicolumn{2}{|c|}{$\begin{array}{l}\text { Number of } \\
\text { productive } \\
\text { tillers/hill } \\
\end{array}$} & \multicolumn{2}{|c|}{$\begin{array}{c}\text { Panicle } \\
\text { length }(\mathrm{cm})\end{array}$} & \multicolumn{2}{|c|}{$\begin{array}{c}\text { Number of } \\
\text { grain/panicle }\end{array}$} \\
\hline & & $\begin{array}{c}\text { Pot } \\
\text { trail }\end{array}$ & $\begin{array}{c}\text { Field } \\
\text { trail }\end{array}$ & $\begin{array}{l}\text { Pot } \\
\text { trail }\end{array}$ & $\begin{array}{c}\text { Field } \\
\text { trail }\end{array}$ & $\begin{array}{l}\text { Pot } \\
\text { trail }\end{array}$ & $\begin{array}{c}\text { Field } \\
\text { trail }\end{array}$ & Pot trail & $\begin{array}{c}\text { Field } \\
\text { trail }\end{array}$ \\
\hline \multirow{6}{*}{$\begin{array}{c}\text { BRRI } \\
\text { Dhan } 28\end{array}$} & $\mathrm{~T}_{1}$ & 67.5h & $68.9 \mathrm{i}$ & $8.3 \mathrm{i}$ & $6.3 \mathrm{i}$ & $16.5 \mathrm{k}$ & $16.3 \mathrm{j}$ & $83.9 \mathrm{~m}$ & $83.7 \mathrm{k}$ \\
\hline & $\mathrm{T}_{2}$ & $88.1 \mathrm{~d}$ & $81.3 \mathrm{~h}$ & 11.0h & $11.0 \mathrm{f}$ & 18.7hi & 18.1hi & $103.1 \mathrm{k}$ & $97.3 \mathrm{j}$ \\
\hline & $T_{3}$ & $93.2 b$ & $93.5 \mathrm{c}$ & $20.7 c$ & $18.3 \mathrm{bc}$ & $22.8 \mathrm{~d}$ & $22.8 \mathrm{~d}$ & $150.8 \mathrm{ef}$ & $150.0 \mathrm{e}$ \\
\hline & $\mathrm{T}_{4}$ & $91.2 \mathrm{c}$ & 79.4h & $16.7 \mathrm{f}$ & $16.7 \mathrm{~d}$ & $22.8 \mathrm{~d}$ & 18.4h & 132.5hi & $135.0 \mathrm{~g}$ \\
\hline & $\mathrm{T}_{5}$ & 93.5b & $91.5 \mathrm{~d}$ & $20.0 \mathrm{~cd}$ & 18.7bc & $22.3 \mathrm{e}$ & $22.2 \mathrm{e}$ & $141.2 \mathrm{~g}$ & $140.0 \mathrm{f}$ \\
\hline & $\mathrm{T}_{6}$ & 93.5b & $98.3 \mathrm{~b}$ & $22.3 \mathrm{~b}$ & $18.9 \mathrm{bc}$ & $22.8 d$ & 23.0d & $152.3 \mathrm{e}$ & $156.3 d$ \\
\hline \multirow{6}{*}{$\begin{array}{c}\text { BRRI } \\
\text { Dhan } 29\end{array}$} & $\mathrm{~T}_{1}$ & $83.5 \mathrm{e}$ & $82.8 \mathrm{~g}$ & $9.7 \mathrm{i}$ & $8.4 \mathrm{~h}$ & $17.8 \mathrm{j}$ & 18.2hi & $96.2 \mathrm{l}$ & $95.0 \mathrm{j}$ \\
\hline & $\mathrm{T}_{2}$ & $89.5 \mathrm{~cd}$ & $87.5 \mathrm{fg}$ & $12.3 \mathrm{~g}$ & $12.3 \mathrm{e}$ & $21.6 \mathrm{f}$ & $21.3 \mathrm{f}$ & $118.0 \mathrm{j}$ & $123.7 \mathrm{i}$ \\
\hline & $\mathrm{T}_{3}$ & $96.3 a$ & $98.7 \mathrm{~b}$ & $22.3 b$ & $21.0 \mathrm{a}$ & $25.3 a$ & $25.3 a$ & $195.0 \mathrm{~b}$ & $228.1 \mathrm{~b}$ \\
\hline & $\mathrm{T}_{4}$ & $91.4 \mathrm{c}$ & 89.2ef & $18.3 \mathrm{e}$ & 18.3bc & $22.8 \mathrm{~d}$ & $22.3 e$ & $169.0 \mathrm{~d}$ & 194.3c \\
\hline & $\mathrm{T}_{5}$ & $95.1 \mathrm{~b}$ & $97.7 \mathrm{~b}$ & $18.7 \mathrm{e}$ & $20.7 \mathrm{a}$ & $24.7 \mathrm{~b}$ & $24.3 \mathrm{~b}$ & $182.3 \mathrm{c}$ & $227.7 \mathrm{~b}$ \\
\hline & $\mathrm{T}_{6}$ & $98.0 \mathrm{a}$ & 103.0a & $23.7 \mathrm{a}$ & $21.7 \mathrm{a}$ & $25.3 a$ & $25.5 a$ & $202.0 \mathrm{a}$ & $235.0 \mathrm{a}$ \\
\hline \multirow{6}{*}{$\begin{array}{c}\text { BRRI } \\
\text { Dhan } 36\end{array}$} & $\mathrm{~T}_{1}$ & $73.5 \mathrm{~g}$ & $70.0 \mathrm{i}$ & $8.7 \mathrm{j}$ & $6.7 \mathrm{i}$ & $16.2 \mathrm{l}$ & $16.1 \mathrm{j}$ & $88.5 \mathrm{~m}$ & 85.0k \\
\hline & $\mathrm{T}_{2}$ & $81.1 \mathrm{f}$ & $80.6 \mathrm{~h}$ & 10.7hi & $9.7 \mathrm{~g}$ & $18.5 \mathrm{i}$ & $18.0 \mathrm{i}$ & 99.01 & $97.0 \mathrm{j}$ \\
\hline & $\mathrm{T}_{3}$ & 89.9cd & $91.5 \mathrm{~d}$ & 19.0de & $18.3 \mathrm{bc}$ & $23.5 c$ & $23.5 c$ & $139.7 \mathrm{~g}$ & $135.0 \mathrm{~g}$ \\
\hline & $\mathrm{T}_{4}$ & 93.5b & $88.6 \mathrm{f}$ & $15.7 \mathrm{f}$ & 17.0d & $19.6 \mathrm{~g}$ & 19.1g & $130.0 \mathrm{i}$ & 129.0h \\
\hline & $\mathrm{T}_{5}$ & $90.5 \mathrm{c}$ & 90.8de & $18.0 \mathrm{e}$ & $18.6 \mathrm{bc}$ & $23.4 \mathrm{c}$ & $22.8 \mathrm{~d}$ & 134.3h & 140.0f \\
\hline & $\mathrm{T}_{6}$ & $94.3 \mathrm{~b}$ & $94.0 \mathrm{c}$ & $21.7 \mathrm{a}$ & $18.7 \mathrm{bc}$ & 23.8bc & $23.9 \mathrm{c}$ & 146.0f & $147.7 \mathrm{e}$ \\
\hline \multicolumn{2}{|c|}{ CV (\%) } & 5.6 & 7.2 & 5.1 & 9.0 & 5.4 & 6.9 & 8.2 & 7.1 \\
\hline
\end{tabular}

$\mathrm{T}_{1}=$ control (no urea or cyanobacteria), $\mathrm{T}_{2}=$ only cyanobacteria, $\mathrm{T}_{3}=$ recommended doses of urea (60 kgN/ha), $\mathrm{T}_{4}=45 \%$ recommended doses of urea + cyanobacteria, $\mathrm{T}_{5}=65 \%$ recommended doses of urea + cyanobacteria and $\mathrm{T}_{6}=85 \%$ recommended doses of urea + cyanobacteria.

In a column and a variety, means followed by the same letter(s) are not differ significantly at $5 \%$ level of probability. 


\section{Number of productive tillers/hill}

Table 1 shows that in pot experiment, BRRI Dhan 36 and BRRI Dhan 29 under $T_{6}$ produced maximum number of productive tillers/hill whereas the lowest number of productive tillers/hill was produced by of BRRI Dhan 28 and BRRI Dhan 36 under $\mathrm{T}_{1}$. In field trial, maximum number of productive tillers/hill was found in BRRI Dhan 29 under $T_{3}, T_{5}$ and $T_{6}$ treatments and the lowest was observed in BRRI Dhan 28 and BRRI Dhan 36 under $\mathrm{T}_{1}$. Such maximum number of tillers was obtained due to algal inoculation combined with nitrogen fertilizer (Sharma and Mishra, 1986). It was observed that cyanobacterial inoculation significantly increased the productive tillers up to about 30\% per unit area (Aiyer et al., 1992) which strongly supports the present findings.

\section{Panicle length}

Panicle length in different varieties of Boro rice showed significant variation for the different treatments both in pots and field trials (Table 1). The BRRI Dhan 29 under $\mathrm{T}_{3}$ and $\mathrm{T}_{6}$ treatments produced the highest panicle length in pot trial whereas BRRI Dhan 36 under $\mathrm{T}_{1}$ produced the shortest panicle. But in field, the BRRI Dhan 29 under $\mathrm{T}_{6}$ treatment produced the tallest panicle whereas the BRRI Dhan 28 and BRRI Dhan 36 under $\mathrm{T}_{1}$ produced the shortest panicle. It was observed that treatments with $\mathrm{N}$ fertilizer and cyanobacteria caused taller plant along with longest panicle and higher number of tiller/plant compared to that for urea alone (Kannaiyan et al., 1982).

\section{Number of grain/panicle}

Both in pot and field experiment, BRRI Dhan 29 under $\mathrm{T}_{6}$ produced the highest number of grain/panicle while BRRI Dhan 28 and BRRI Dhan 36 under $\mathrm{T}_{1}$ produced the lowest (Table 1). Highest number of filled grain/panicle was obtained due to split application of cyanobacteria with urea (Karim \& Rahaman, 1992). Application of cyanobacteria with urea increased the number of grain/panicle both in pot and field trials (Rao et al., 1997). This finding agreed well with the present study.

\section{0-grain weight}

In pot experiment, the 1000-grain weight was found maximum in BRRI Dhan 29 under $\mathrm{T}_{6}$ and the lowest was observed in BRRI Dhan 28 and BRRI Dhan 36 under $\mathrm{T}_{1}$ (Table 2). In field, the 1000-grain weight was observed maximum in BRRI Dhan 29 under $T_{3}, T_{5}$ and $T_{6}$ whereas the lowest was found in BRRI Dhan 28 under $T_{1}$. This finding almost agreed with the investigation of Suri \& Puri (1994). They obtained highest 1000 grain weight by $\mathrm{BGA}_{10}+\mathrm{N}_{90}$ (cyanobacteria at $10 \mathrm{~kg} \mathrm{ha}^{-1}$ and nitrogen at $90 \mathrm{~kg} / \mathrm{ha}$ ) in rice. On the other hand, it was also reported that 1000 grain weight was greater due to incorporation of cyanobacteria (Kannaiyan et al., 1982).

\section{Grain and straw yield}

Grain and straw yield, varied significantly among the treatments both in pot and field experiments. The highest grain yield both in pot and field was observed in BRRI Dhan 29 under $\mathrm{T}_{6}$ and the lowest was found in BRRI Dhan 28 under $\mathrm{T}_{1}$ (Table 2). The highest straw yield was observed in BRRI Dhan 29 under $\mathrm{T}_{6}$ and the lowest was found in BRRI Dhan 28 under $\mathrm{T}_{1}$ both in pot and field experiment (Table 2). It was observed that the increase of grain yield over the control ranged between 3-14\% with incorporation of cyanobacteria (Jagannathan et al., 1988). It was reported that direct 
application of cyanobacteria significantly increased the grain and straw yield of rice (Sharma, 1969). It was also observed that the effect of cyanobacteria alone or in combination with urea increased grain and straw yield (Venkataraman, 1979). It was stated that in areas where chemical $\mathrm{N}$ fertilizers were not used, only cyanobacterial inoculation gave the benefits of the farmers equivalent of applying $25-30 \mathrm{~kg} \mathrm{~N} \mathrm{ha}^{-1}$. Where $\mathrm{N}$ fertilizer was used, the dozes could be reduced by about one-third through cyanobacterial inoculation.

Table 2. Effect of cyanobacteria on the yield of boro rice with different levels of urea both in pot and field trails.

\begin{tabular}{|c|c|c|c|c|c|c|c|c|c|}
\hline \multirow[t]{2}{*}{ Varieties } & \multirow{2}{*}{$\begin{array}{l}\text { Treat } \\
\text { ments }\end{array}$} & \multicolumn{2}{|c|}{$\begin{array}{l}\text { Plant height } \\
(\mathrm{cm}) \text { at } \\
\text { maturity stage }\end{array}$} & \multicolumn{2}{|c|}{$\begin{array}{l}\text { Number of } \\
\text { productive } \\
\text { tillers/hill }\end{array}$} & \multicolumn{2}{|c|}{$\begin{array}{l}\text { Panicle } \\
\text { length }(\mathrm{cm})\end{array}$} & \multicolumn{2}{|c|}{$\begin{array}{c}\text { Number of } \\
\text { grain/panicle }\end{array}$} \\
\hline & & $\begin{array}{l}\text { Pot } \\
\text { trail }\end{array}$ & $\begin{array}{c}\text { Field } \\
\text { trail }\end{array}$ & $\begin{array}{l}\text { Pot } \\
\text { trail }\end{array}$ & $\begin{array}{c}\text { Field } \\
\text { trail }\end{array}$ & $\begin{array}{l}\text { Pot } \\
\text { trail }\end{array}$ & $\begin{array}{l}\text { Field } \\
\text { trail }\end{array}$ & $\begin{array}{l}\text { Pot } \\
\text { trail }\end{array}$ & $\begin{array}{l}\text { Field } \\
\text { trail }\end{array}$ \\
\hline \multirow{6}{*}{$\begin{array}{c}\text { BRRI Dhan } \\
28\end{array}$} & $\mathrm{~T}_{1}$ & $19.3 \mathrm{i}$ & $19.4 \mathrm{i}$ & $154.4 \mathrm{k}$ & $3.6 \mathrm{i}$ & $4.6 q$ & $4.7 \mathrm{~m}$ & $8.2 \mathrm{~h}$ & $8.3 \mathrm{~g}$ \\
\hline & $\mathrm{T}_{2}$ & 20.4h & $20.5 \mathrm{~g}$ & 155.3h & $4.2 \mathrm{gh}$ & 5.30 & $5.4 \mathrm{k}$ & $9.5 f$ & $9.6 f$ \\
\hline & $\mathrm{T}_{3}$ & $22.0 \mathrm{~d}$ & $21.9 \mathrm{c}$ & $156.8 \mathrm{c}$ & $5.5 \mathrm{~cd}$ & $7.3 c$ & 7.4cd & $12.8 \mathrm{c}$ & $12.9 \mathrm{c}$ \\
\hline & $\mathrm{T}_{4}$ & $21.0 \mathrm{f}$ & $20.9 \mathrm{f}$ & $155.5 \mathrm{f}$ & $4.9 \mathrm{ef}$ & $6.2 \mathrm{l}$ & $7.3 \mathrm{bc}$ & $10.9 \mathrm{e}$ & $12.3 \mathrm{~cd}$ \\
\hline & $\mathrm{T}_{5}$ & $21.9 d$ & $21.7 \mathrm{~d}$ & $156.1 \mathrm{e}$ & 5.1de & $6.6 \mathrm{j}$ & 6.6gh & $11.7 \mathrm{~d}$ & $11.7 \mathrm{~d}$ \\
\hline & $\mathrm{T}_{6}$ & $22.0 \mathrm{~d}$ & $21.9 \mathrm{c}$ & 156.6c & 5.6d & $6.9 \mathrm{~g}$ & $6.9 \mathrm{e}$ & $12.4 \mathrm{c}$ & $12.5 \mathrm{c}$ \\
\hline \multirow{6}{*}{$\begin{array}{c}\text { BRRI Dhan } \\
29\end{array}$} & $\mathrm{~T}_{1}$ & $19.7 \mathrm{i}$ & 21.f & $154.7 \mathrm{i}$ & 4.1gh & $5.0 \mathrm{p}$ & 5.1 & $8.9 \mathrm{~g}$ & $9.1 \mathrm{f}$ \\
\hline & $\mathrm{T}_{2}$ & $21.3 \mathrm{e}$ & $22.2 \mathrm{~b}$ & $155.5 \mathrm{f}$ & 5.3de & $5.7 \mathrm{n}$ & $5.7 \mathrm{j}$ & $9.9 \mathrm{f}$ & $11.0 \mathrm{e}$ \\
\hline & $\mathrm{T}_{3}$ & $22.6 \mathrm{~b}$ & $23.4 \mathrm{a}$ & $157.6 \mathrm{~b}$ & $6.5 \mathrm{~b}$ & $7.6 \mathrm{~b}$ & $6.7 \mathrm{f}$ & $14.4 \mathrm{a}$ & $13.2 \mathrm{~b}$ \\
\hline & $\mathrm{T}_{4}$ & $21.9 \mathrm{~d}$ & $22.3 \mathrm{~b}$ & $156.1 \mathrm{~d}$ & $5.9 \mathrm{c}$ & $6.7 \mathrm{i}$ & $7.2 \mathrm{~d}$ & $11.9 \mathrm{~d}$ & $13.2 \mathrm{~b}$ \\
\hline & $\mathrm{T}_{5}$ & $22.2 \mathrm{c}$ & $23.2 \mathrm{a}$ & $157.7 \mathrm{~b}$ & $6.5 \mathrm{~b}$ & $7.1 \mathrm{f}$ & $7.4 \mathrm{~b}$ & $13.8 \mathrm{~b}$ & $13.9 \mathrm{~b}$ \\
\hline & $\mathrm{T}_{6}$ & $22.8 \mathrm{a}$ & $23.4 a$ & 158.0a & $7.1 \mathrm{a}$ & $7.7 \mathrm{a}$ & $7.8 \mathrm{a}$ & $14.7 \mathrm{a}$ & $14.9 \mathrm{a}$ \\
\hline \multirow{6}{*}{$\begin{array}{l}\text { BRRI Dhan } \\
36\end{array}$} & $\mathrm{~T}_{1}$ & $19.8 \mathrm{i}$ & 19.9h & $154.9 \mathrm{j}$ & 3.9hi & $7.1 \mathrm{e}$ & $5.2 \mathrm{k}$ & $10.7 \mathrm{e}$ & $9.1 \mathrm{f}$ \\
\hline & $\mathrm{T}_{2}$ & $20.8 \mathrm{~g}$ & $20.6 \mathrm{~g}$ & $155.6 \mathrm{~g}$ & $4.5 f g$ & $7.2 \mathrm{~d}$ & $7.0 \mathrm{~d}$ & 11.7d & $11.5 \mathrm{de}$ \\
\hline & $\mathrm{T}_{3}$ & $22.0 \mathrm{~d}$ & $21.9 \mathrm{c}$ & $156.0 \mathrm{e}$ & 5.2de & $6.1 \mathrm{~m}$ & 7.3cd & $11.2 \mathrm{~cd}$ & $12.5 \mathrm{c}$ \\
\hline & $\mathrm{T}_{4}$ & $21.0 \mathrm{f}$ & $21.0 \mathrm{f}$ & $155.6 \mathrm{f}$ & $4.9 \mathrm{ef}$ & $6.5 \mathrm{k}$ & $6.1 \mathrm{i}$ & 11.3cd & $10.9 \mathrm{e}$ \\
\hline & $\mathrm{T}_{5}$ & $22.0 \mathrm{~d}$ & $21.7 \mathrm{~d}$ & 156.1e & 5.1de & $6.8 \mathrm{~h}$ & $6.7 \mathrm{~h}$ & $11.8 \mathrm{~d}$ & $11.8 \mathrm{~d}$ \\
\hline & $\mathrm{T}_{6}$ & $22.1 \mathrm{c}$ & $21.5 \mathrm{e}$ & 156.3e & $5.8 \mathrm{c}$ & 7.1ef & 6.9ef & $12.2 \mathrm{c}$ & $12.7 \mathrm{c}$ \\
\hline \multicolumn{2}{|c|}{ CV (\%) } & 3.5 & 6.1 & 6.2 & 4.9 & 7.2 & 6.9 & 5.3 & 5.6 \\
\hline
\end{tabular}

$\mathrm{T}_{1}=$ control (no urea or cyanobacteria), $\mathrm{T}_{2}=$ only cyanobacteria, $\mathrm{T}_{3}=$ recommended doses of urea (60 kgN/ha), $\mathrm{T}_{4}=45 \%$ recommended doses of urea + cyanobacteria, $\mathrm{T}_{5}=65 \%$ recommended doses of urea + cyanobacteria and $\mathrm{T}_{6}=85 \%$ recommended doses of urea + cyanobacteria.

In a column and a variety, means followed by the same letter(s) are not differ significantly at $5 \%$ level of probability.

\section{Biological yield}

Data presented in Table 2 show that the BRRI Dhan 29 under $\mathrm{T}_{3}$ and $\mathrm{T}_{6}$ produced the highest biological yield in pot experiment. On the other hand, BRRI Dhan 28 under $\mathrm{T}_{1}$ produced the lowest biological yield. In case of field experiment, BRRI Dhan 29 under $\mathrm{T}_{6}$ was also produced the highest biological yield and BRRI Dhan 28 under $\mathrm{T}_{1}$ produced the lowest (Table 2). Biological yield refers to the sum of grain and straw yields. Total yield (grain + straw) responded significantly to simultaneous growth of 
cyanobacteria with rice plants. The highest biological yield was found in BRRI Dhan 29 under $\mathrm{T}_{6}$ and the lowest biological yield was found in BRRI Dhan 28 under $\mathrm{T}_{1}$ both in pot and field experiments. It was reported that direct application of cyanobacteria significantly increased the grain and straw yield of rice (Sharma, 1969). Cyanobacteria reduced $15-20 \%$ use of nitrogenous fertilizers (urea) for optimum biological yield of Boro rice in the present study. The positive effects of cyanobacteria in increasing rice yields were also well reported Karim \& Rahman (1992) and Antarikanonda \& Amarit (1991).

Most of the farmers of the studied area were found unaware of the adverse effects of agro chemicals and beneficial effects of bio fertilizer. Their knowledge on unfavorable effect of chemical fertilizer on human health, soil and soil micro organisms, water and environment is very poor. Thus the farmers may be suggested for using cyanobacteria as well as other bio fertilizers reducing the amount of agro chemicals in the rice field.

\section{References}

Aiyer, R.S., Salahudeen, S. \& Venkataraman, G.S. 1992. Long term algalization field trial with high yielding varieties of Rice (Oryza sativa L). Indian Jour. Agric. Science, 42(5):330-385.

Antarikanonda, P. \& Amarit, P. 1991. Influence of blue-green algae and nitrogen fertilizer on rice yield in saline soils. Kasetsart J. Nat Sci., 25(1):18-25.

BARC. 1998. Fertilizer recommendation guide. Bangladesh Agricultural Research Council, Dhaka, 5-10.

Chowdhury, A.T.M.A. \& Bhuiyan, N.I. 1999. Yield and nitrogen nutrient of modern rice as affected by nitrogen fertilizer under irrigated culture. Bangladesh Rice J., 2(1\&2): 122-127.

Gomez, K.A. \& Gomez, A.A. 1984. Statistical procedures for agricultural research. $2^{\text {nd }}$ ed. Johv Willey and Sons, Singapore, 207-215.

Islam, A. 1984. Review of soil fertility research in Bangladesh. Proc. Int. Sym. Soil test crop response correlation studies. Dhaka. 7-10 February 1984:2-7.

Jagannathan, R., Kannaiyan, S. \& Palaniyandi, V.G. 1988. Residual effect of blue green algae application on rice yield. Int. Rice Res. Newsl., 3(4):20.

Kannaiyan, S., Govindarajan, K.H.D. \& Venkataraman, G.S. 1989. Effect of inoculation of blue-green algae on rice crop. IRRN, 4:11.

Kannaiyan, S.K., Govindarajan, H.D. \& Venkatarama, G.K. 1982. Influence of blue-green algal application on rice crop. Madras Agric. Jour, 69(1): 1-5.

Karim, M.M. \& Rahman, M. 1992. Effect of nitrogen and blue-green algae on the performance of Rice. Bangladesh Jour. Agric. Science, 19(1): 99-102.

Mian, M.H. 1994. Verification of national fertilizer recommendation in Sonatala and Ghatail series of Mymensingh district. BAU Res. Prog., 8:129-138.

Rao, L.J., Venkatachari, A., Rao, W.V.B.S. \& Reddy, K.R. 1997. Individual and combined effect of bacterial and algal inoculation on the yield of rice. Current Sci., 46(2): 50-51. 
Sattar, M.A. 1972. A study on the transformation of Urea-N in soils. M.Sc. (Ag) thesis, Department of Soil Science, Bangladesh Agricultural University.

Sharma, D.N. 1969. Influence of blue-green algae on the yield of paddy crop in presence and absence of organic matter and phosphate in field. Indian J. Agric. Chem., 2: 22-26.

Sharma, M.L. \& Mishra, V.R. 1986. Effect of fertilizer nitrogen and algal inoculation on rice crop. Madras Agric. J., 73: 155-159.

Suri, V.K. \& Puri, U.K. 1994. Blue green algae as a potential biofertilizer for rice. Ann. Agric. Res., 15(4): 502-503.

Venkataraman, G.S. 1979. Algal inoculation of rice fields. In: Patnaik, S. Rao, M.V. (eds): Nitrogen and rice symposium proceedings. International Rice Research Institute, Manila: 311-321. 